\title{
Slurry surfacing: a review of definitions, descriptions and current practices
}

\author{
Andrea Grillia, Andrea Graziani ${ }^{\mathrm{b} *}$, Alan Carter ${ }^{\mathrm{c}}$, Cesare Sangiorgi ${ }^{\mathrm{d}}$, Luciano Pivoto Specht ${ }^{\mathrm{e}}$, Sergio Copetti \\ Callai $^{\mathrm{d}}$
}

a Università della Repubblica di San Marino, Repubblica di San Marino

${ }^{b}$ Università Politecnica delle Marche, Ancona, Italy

cÉcole de Technologie Supérieure, Monteral, Canada

dUniversità di Bologna, Italy

e Universidade Federal de Santa Maria, Brasil

Received: 03 April 2019 / Accepted: 21 October 2019 / Published online: 19 November 2019

(C) The Author(s) 2019. This article is published with open access and licensed under a Creative Commons Attribution 4.0 International License.

\begin{abstract}
Cold bitumen emulsions (CBE) are currently used worldwide for both non-structural (cold surface treatments) and structural (cold bituminous mixtures) paving applications. Among non-structural applications, bituminous slurry surfacings (BSS) allow to improve surface properties and extend the pavement's life. However, selection of constituents, mix design, application and quality control procedures for BSS are mostly based on local experience and empirical tests. Thus, the use of BSS is associated to higher technical risks with respect to the use of traditional hot-mix technologies.

In this context the RILEM Technical Committee 280-CBE TG2 “Multiphase characterisation of cold bitumen emulsion materials" aims to collect worldwide theoretical knowledge and experiences on BSS and to inspire new standards, specifications and guidelines encompassing the wide set of existing practices. This paper summarizes the first part of the literature review carried out as part of the TC workplan and focuses on the definition, the description and the application method for BSS. National standards, construction specifications and best practice documents from North America, South America, Europe and Australia are analysed and compared.
\end{abstract}

Keywords: Cold bitumen emulsion technologies; surface treatment; slurry seal; microsurfacing; literature review

\section{Introduction}

Bitumen emulsions play a key role in the development of sustainable and durable pavements. It is known that the bitumen/water emulsification process reduces the binder viscosity, allowing the production of paving mixtures at ambient temperature and in most cases even without aggregate drying and heating [1,2]. Cold bitumen emulsion (CBE) mixtures allow important energy savings and reduction of emissions, they can effectively contribute to reduce the impacts of the road industry, while maintaining high standards of performance and safety of the infrastructure.

CBE technologies are currently used for both non-structural (cold surface treatments such as chip seals or slurry seals) and structural (cold bituminous mixtures, cold recycled bituminous mixtures, grave emulsion) paving applications [3]. However, the lack of fundamental knowledge on how to merge the mechanical behaviour of CBE mixtures and the inservice evidences of their long-term performance seems to hinder the broad use of CBE technologies which are often associated to higher technical risks with respect to traditional hot-mix or warm-mix technologies.

In this context, the RILEM Technical Committee 280-CBE TG2 "Multiphase characterisation of cold bitumen emulsion materials" was formed with the aim of improving the fundamental knowledge on CBE materials and suggest worldwide harmonisation of existing standards and practices [4]. The activities of the Task Group 2 focus on non-structural applications of CBE technologies and specifically on bituminous slurry surfacings (BSS). A thorough literature review was initiated, to collect worldwide theoretical knowledge and field experiences on BSS.

The objective of this paper is to summarize the first results of this review and propose harmonised definitions and descriptions for BSS. Moreover, typical applications of BSS are reviewed, and two examples are presented and discussed to illustrate current practices.

\footnotetext{
* Corresponding author: Andrea Graziani, E-mail: a.graziani@univpm.it, Tel. +39 0712204507
} 


\section{Background}

Surface treatment is a broad term embracing several superficial application methods of bituminous binder or engineered additive with or without aggregate [3]. Surface treatments are used to extend the pavement's life and thus generally are part of the road maintenance process. They are applied on the aged and distressed pavement surface to restore its structural integrity, evenness, skid resistance and impermeability.

The most common binder used in surface treatments is bitumen emulsion (which may be modified with polymers). Recently, bitumen-extended epoxy resins, epoxy resin or translucent synthetic binder have been used with satisfactory results in terms of setting, adhesion to most surfaces and aesthetics $[5,6]$.

Three main types of emulsion-based surface treatment can be distinguished: spray-applied seal, surface dressing (or chip seal) and BSS. In spray-applied seals only bitumen emulsion is applied on the road surface in order to seal cracks, to reduce ravelling and to repair weathered surfaces. Chip seals (Figure 1a) are characterized by at least one layer of bitumen emulsion and one layer of chippings (single-size aggregate fraction) which are applied in sequence, without mixing, over the road surface to restore its surface evenness, to seal cracks, to reduce ravelling and to improve skid resistance. BSS (Figure $1 \mathrm{~b}$ ) are mixtures of aggregates, binder and additives which are applied on the road surface to improve traffic lane visibility, to seal cracks, to fill minor depressions and to provide high skid resistance.

Currently, selection of constituent materials, mix design, application and quality control procedures for BSS are mainly based on experience-related empirical or practical rules. The comparison among practical knowledge adopted in different countries and the gradual understanding of the mechanical properties should lead to combine the scientific and fieldbased approaches for a more effective and diffuse application.

Table 1 shows the list of the collected public documents such as standards, best practices and specifications. The use of an incomplete standards' list and different methods or parameters for the characterisation of the constituent

(a)

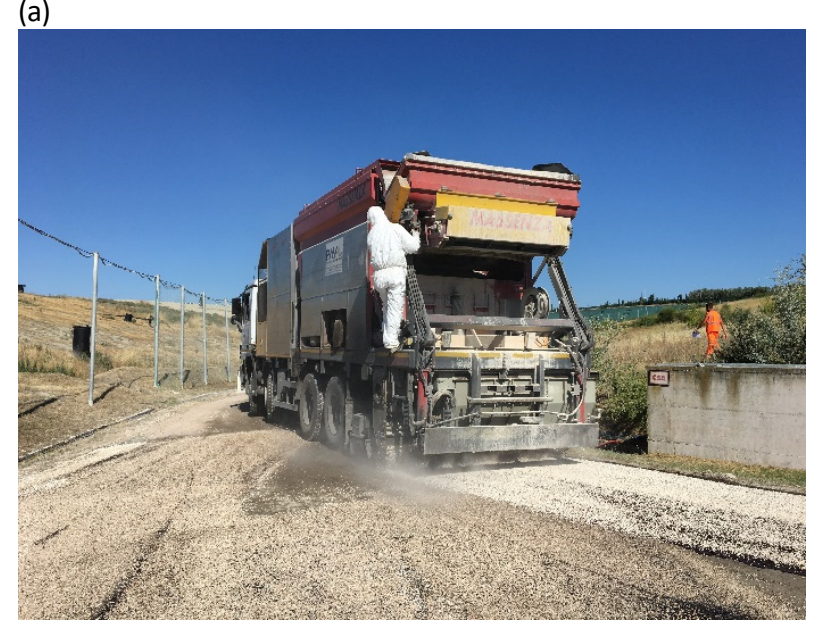

materials or products have been the main difficulties in the analysis and comparison of the requirements and procedures among the participating countries.

\section{Definition}

Currently, the general definition of slurry surfacing is not univocally shared worldwide. Often slurry surfacings are simply described by road agencies or technical associations giving a list of constituent materials.

In the Austroads guidelines AP-T26 [19] the term "slurry" is used to indicate "stable suspension of aggregate and filler in a less dense, liquid bituminous emulsion". In the fresh state, the liquid consistence makes BSS self-levelling. Taking this remark as a starting point and analysing the used terminology, slurry surfacings represent a family of mixtures which generally share consistency (slurry) and applications (surfacing) with no specific indication on the binder or aggregate to be used.

A slurry surfacing can be defined as a mixture that is characterized by a slurry state (i.e. free flowing with a definite volume but no fixed shape, having higher density and consistence than a liquid). After laying, it evolves into a solid state during a curing process that takes generally from half an hour to twelve hours. This evolutive behaviour clearly distinguish slurry surfacing from other surface treatments like spray-applied seals and surface dressing.

As the name implies, the use of bitumen emulsion as binder identifies BSS. Among BSS products, slurry seals and microsurfacings can be distinguished and selected for specific performance and uses based on their maximum aggregate size and the bituminous binder type.

As stated by the Arizona Chapter Associated General Contractors [15] "although microsurfacing and slurry seals are generally similar, microsurfacing is designed to facilitate a quicker return to traffic, heavier application rate, rut filling and support higher traffic volume". Accordingly, the International Slurry Surfacing Association (ISSA) [13] asserts that "micro surfacing is a quick-traffic system that allows traffic to return shortly after placement".

(b)

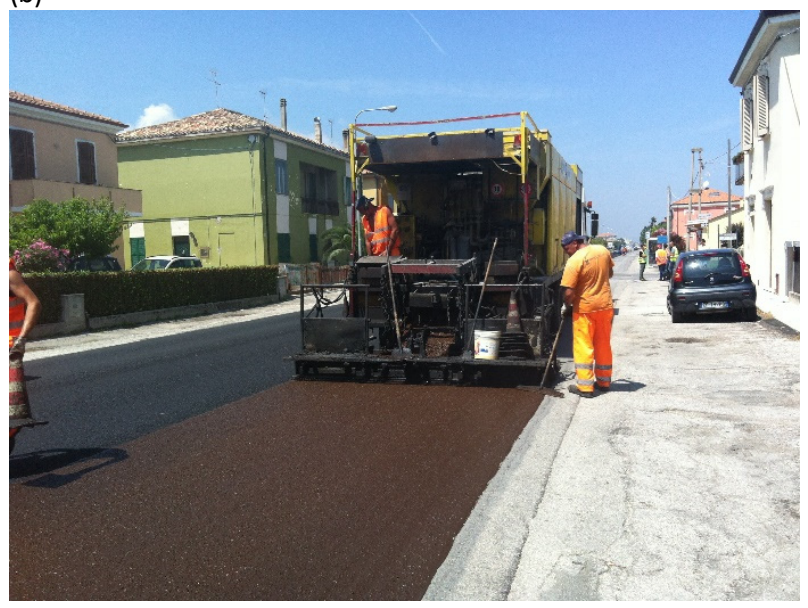

Figure 1. Two example applications of emulsion-based surface treatment: a) Surface dressing; b) Bituminous slurry surfacing. 
Table 1. List of the considered documents.

\begin{tabular}{|l|l|l|l|}
\hline Country & $\begin{array}{l}\text { National/International } \\
\text { Standard }\end{array}$ & Best practice/Guideline & Construction Specification \\
\hline Australia & - & Austroads [19] & Austroads [19] \\
\hline Brazil & DNIT [10] & Instituto Pavimentar [18] & - \\
\hline Canada, USA & ASTM [8] & ISSA [13,14], AZAGC [15] & - \\
\hline China & - & - & JTG [24] \\
\hline Czech Republic & CEN [7], ČSN [11] & - & Ministerstvo Dopravy [24] \\
\hline France & CEN [7] & CEREMA [5] & - \\
\hline Italy & CEN [7] & SITEB [12] & CIRS [20], ANAS [21], Autostrade per I'Italia [22] \\
\hline Portugal & CEN [7] & - & Estradas de Portugal [23] \\
\hline Spain & CEN [7] & ATEB, [16,17] & - \\
\hline Switzerland & CEN [7], VSS [9] & - & - \\
\hline
\end{tabular}

The Austroads guidelines AP-T26 [19] defines microsurfacing as a "bituminous slurry surfacing, usually containing polymer, which is capable of being spread in variably thick layers for rutfilling and correction courses, and for wearing course applications requiring good surface texture". A slurry seal, instead, is defined as a "thin layer of bituminous slurry surfacing, usually without a polymer modifier".

Considering the technology development over time, slurry seal can be identified as the first generation of BSS, aimed to seal old pavement surfaces. Microsurfacing can be considered as the second generation of BSS, following from the development of more advanced construction equipment and the improvement of binder performance. Microsurfacing is characterised by higher performance, faster setting and curing time, therefore, it allows more durable applications, heavier traffic volume, quicker traffic opening. This is probably the reason why, in many countries, such as Italy, Brazil and Czech Republic, the use of slurry seals has dropped, and it has been replaced by microsurfacing, especially on heavy traffic pavements. In Brazil and Czech Republic, the use of slurry seals is now limited to small towns, fast temporary maintence and low volume roads in the countryside.

\section{Description}

BSS is a bituminous mixture consisting of a well-graded aggregate blend, water, bituminous emulsion (which may be modified) and filler (which may include Portland cement, hydrated lime, limestone dust, fly ash or a combination of them) $[12-15,19]$. Specific additives and fibres may also be included $[5,18,20,21]$ to improve affinity with aggregates, consistency or setting time. As different expertise and application methods exist around the world, the constituent materials of BSS can be proportioned considering a wide range of dosages (Table 2).
BSS is proportioned, mixed and uniformly laid in-place at ambient temperature, over a properly prepared surface. It is applied as a homogeneous mat, adheres firmly to the pavement and has a skid-resistant texture throughout its service life (Figure 2). BSS may consist of one or two layers, usually each with the thickness of the largest aggregate size in the gradation.

As stated before, some differences arise when comparing the descriptions of slurry seals and microsurfacings from different countries, even if their general design is globally consistent. Microsurfacing is commonly considered different from slurry seal for the use of polymer-modified emulsion and superior aggregate quality. Moreover, the nominal maximum size for microsurfacing is often larger than that used in slurry seal. It is worth noting that the European Norm EN 12273 [7] makes distinction between microsurfacing and slurry seal only on the basis of aggregate size ("slurry surfacing made with larger size aggregates is often known as micro-surfacing and when made with smaller aggregates is sometimes called slurry seal").

According to ISSA guidelines [13,14], slurry seal and microsurfacing share two aggregate bands, type II $\left(D_{\max }=4.75\right.$ $\mathrm{mm}$ ) and type III ( $\left.D_{\max }=6.70 \mathrm{~mm}\right)$, whereas type I $\left(D_{\max }=2.36\right.$ $\mathrm{mm}$ ) is used only for slurry seal.

The Portuguese specifications [23] adopt slurry seal and micro surfacing with the same aggregate band when applied in a single layer $\left(D_{\max }=5.6 \mathrm{~mm}\right)$. On the other hand, when they are applied in a double layer, they share only the aggregate band for the first layer $\left(D_{\max }=2 \mathrm{~mm}\right)$. For the second layer, microsurfacing requires larger aggregates $\left(D_{\max }=8 \mathrm{~mm}\right)$ than slurry seal $\left(D_{\max }=5.6 \mathrm{~mm}\right)$. Table 3 [17] summarizes the differences between slurry seal and microsurfacing based on Brazilian experience.

Table 2. Typical dosage ranges for BSS components.

\begin{tabular}{|l|l|l|}
\hline Material & Typical values & Recommendation \\
\hline Bitumen [\% by aggregate weight] & $6-16$ & the finer the aggregate size, the higher the bitumen dosage \\
\hline Filler [\% by aggregate weight] & $0-3$ & $\begin{array}{l}\text { depending on bituminous emulsion properties, mechanical behaviour and } \\
\text { climate }\end{array}$ \\
\hline Mixture application rate $\left[\mathrm{kg} / \mathrm{m}^{2}\right]$ & $4-30$ & the finer the aggregate size, the lower the application rate \\
\hline
\end{tabular}



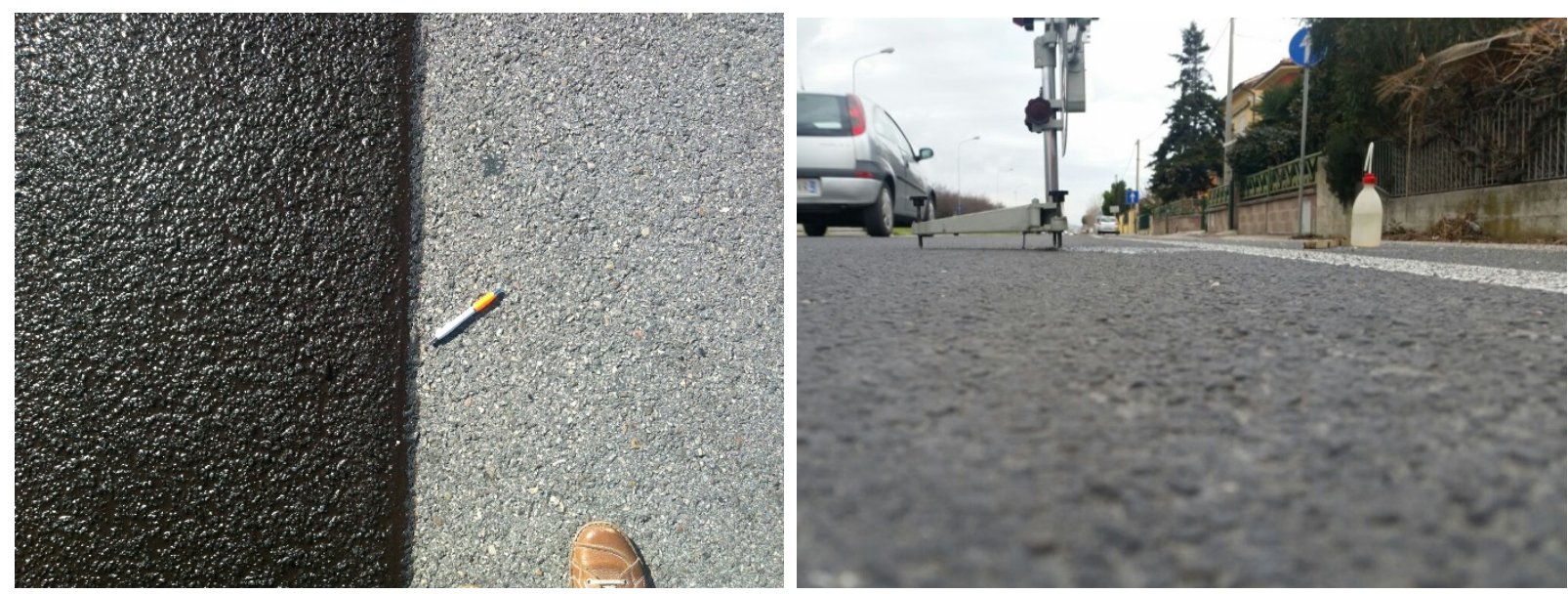

Figure 2. Example of an application of BSS in fresh state and after setting in Italy.
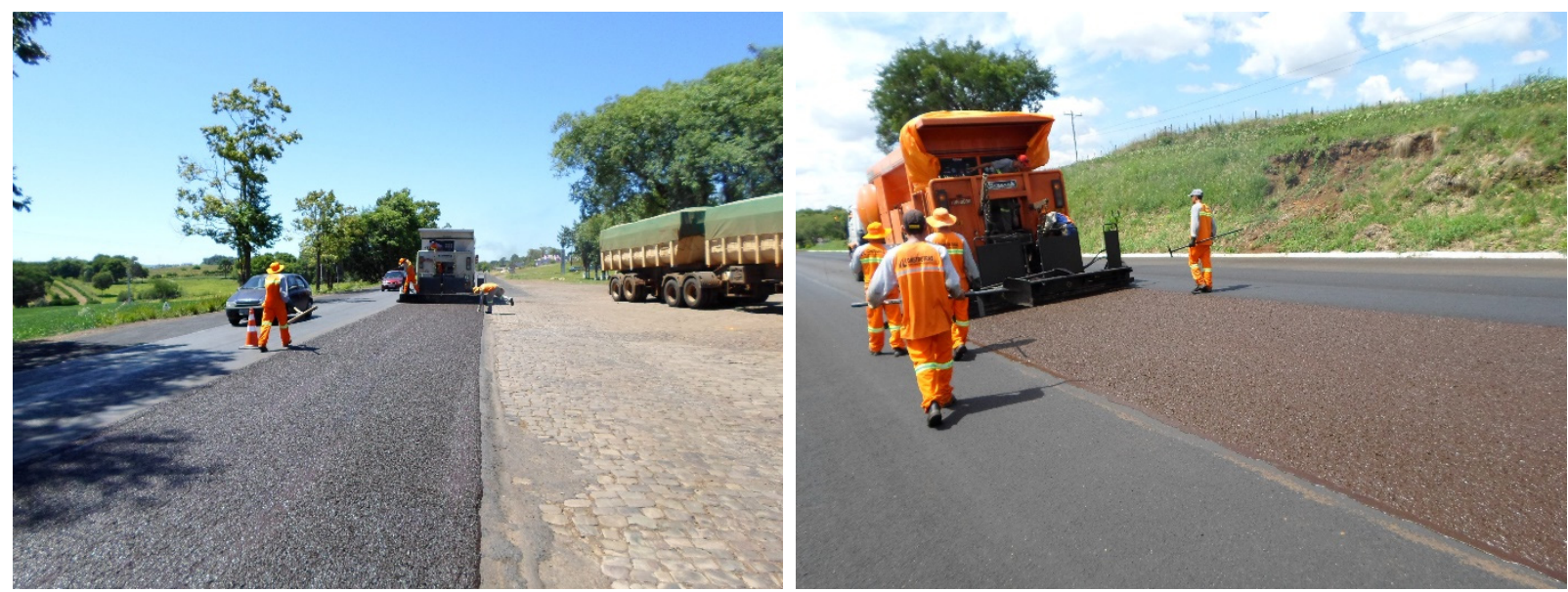

Figure 3. Example of an application of microsurfacing in Brazil.

Table 3. Difference between slurry seal and micro surfacing from Brazilian experiences.

\begin{tabular}{|l|l|}
\hline Slurry seal & Microsurfacing \\
\hline Smooth-textured aggregate can be used & Crushed and high-quality aggregate must be used. Generally larger in size \\
\hline Slow setting bituminous emulsion & Modified (elastomeric) bituminous emulsion with controlled setting \\
\hline Climatic conditions have a paramount impact on curing evolution & $\begin{array}{l}\text { Chemical process, along with climatic conditions, controls curing } \\
\text { evolution }\end{array}$ \\
\hline $\begin{array}{l}\text { Mainly used for sealing and rejuvenating road pavements } \\
\text { subjected to low or medium traffic volume }\end{array}$ & $\begin{array}{l}\text { Mainly used for improving skid resistance and levelling road pavements } \\
\text { subjected to any traffic level }\end{array}$ \\
\hline Service life of about 3-5 years & Service life of about 5-8 years \\
\hline Closing time to traffic of about 4 hours & Closing time to traffic of about 1 hours \\
\hline Could require a tack coat & Good adhesion to existing pavement \\
\hline Average cost: $0.90 € / \mathrm{m}^{2}$ & Average cost: $2.00 € / \mathrm{m}^{2}$ \\
\hline
\end{tabular}

\section{Current practice}

BSS is used to maintain and extend the service life of existing bituminous pavements through improving resistance to abrasion by traffic and providing a waterproof cover over an old pavement surface. Moreover, according to the French technical guidelines [5] BSS can also be used in new construction, when traffic levels are less than 300 vehicles/day.

Table 4 summarizes the main applications of slurry seal and microsurfacing in different countries. As can be observed they are normally adopted:
- $\quad$ to prevent surface water from penetrating the underlying pavements;

- to restore or to improve skid resistance of the aged pavement;

- to restore weathered surfaces giving new life to oxidized and ravelled pavements;

- to fill surface voids and microcracking;

to improve the aesthetics of an existing pavement providing a distinctive colour to the road surface, a more uniform appearance to a patched road, to contrast with road marking and a homogeneous surface helping in selecting specific lane or route. 
Table 4. Main functions of slurry seal (SS) and microsurfacing (MS) in different countries.

\begin{tabular}{|c|c|c|c|c|c|c|c|c|c|c|}
\hline & & \multicolumn{9}{|l|}{ Country } \\
\hline & & 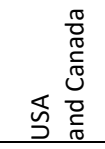 & $\begin{array}{l}\overline{0} \\
00 \\
\frac{0}{2} \\
\frac{1}{0} \\
0\end{array}$ & $\begin{array}{l}\frac{0}{c} \\
\frac{0}{\pi} \\
\frac{1}{N} \\
\stackrel{N}{3} \\
n\end{array}$ & $\begin{array}{l}\frac{1}{\pi} \\
\stackrel{0}{n}\end{array}$ & 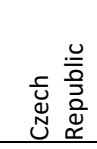 & $\begin{array}{l}\frac{\pi}{\pi} \\
\frac{0}{2} \\
\frac{\hbar}{2}\end{array}$ &  & 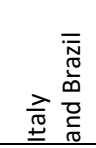 & 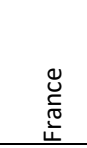 \\
\hline \multirow{9}{*}{  } & Waterproofing & $\mathrm{SS}+\mathrm{MS}$ & $\mathrm{SS}+\mathrm{MS}$ & $\mathrm{SS}+\mathrm{MS}$ & SS+MS & SS+MS & $\mathrm{SS}+\mathrm{MS}$ & SS+MS & MS & SS+MS \\
\hline & Improve skid resistance & $\mathrm{SS}+\mathrm{MS}$ & $\mathrm{SS}+\mathrm{MS}$ & $\mathrm{SS}+\mathrm{MS}$ & $\mathrm{SS}+\mathrm{MS}$ & SS+MS & $\mathrm{SS}+\mathrm{MS}$ & $\mathrm{SS}+\mathrm{MS}$ & MS & MS \\
\hline & Prevent ravelling & $\mathrm{SS}+\mathrm{MS}$ & - & - & - & $\mathrm{SS}+\mathrm{MS}$ & $\mathrm{SS}+\mathrm{MS}$ & $\mathrm{SS}+\mathrm{MS}$ & - & - \\
\hline & Fill superficial voids and cracking & $\mathrm{SS}+\mathrm{MS}$ & - & - & - & $\mathrm{SS}+\mathrm{MS}$ & $\mathrm{SS}+\mathrm{MS}$ & SS+MS & - & MS \\
\hline & Improve aesthetics & $\mathrm{SS}+\mathrm{MS}$ & MS & - & - & - & - & SS+MS & MS & SS+MS \\
\hline & Temporary cover at low cost & SS & - & - & - & SS & - & - & - & - \\
\hline & Provide smooth surfaces $*$ & - & - & - & - & SS & SS & - & - & - \\
\hline & Shape correction and reprofiling & MS & & MS & - & MS & $\mathrm{MS}$ & MS & MS & - \\
\hline & Durability and fast traffic opening & MS & MS & MS & MS & MS & MS & MS & MS & - \\
\hline
\end{tabular}

Slurry seal also has the following additional specific uses (Table 4):

- to provide temporary cover at low cost;

- to provide smooth surfaces for pedestrian areas, car parking lots, school yards and bicycle tracks.

Whereas microsurfacing is specifically chosen:

- to provide shape correction and reprofiling rutted wheelpaths;

- to achieve longer durability and faster traffic opening.

Slurry seals are mainly used in urban areas or in low-volume roads. However, in Australia and France, they are also used in airfields to restore skid resistance and to serve as preventive maintenance reducing the risk of coarse aggregate being plucked out of the surface to be hit by airplane propellers or ingested into jet engines. Moreover, Austroads reports that slurry seal can be applied as an alternative to sprayed sealing, for example, within urban areas where traffic noise from a sprayed seal would not be acceptable [19].

On the other hand, microsurfacing offers a wider range of application contexts. In some cases, it is considered as an alternative to traditional hot or warm bituminous mixtures. For instance, in Italy, microsurfacing applications over new pavement were carried out to provide a cost-effective and time saving alternative to a traditional wearing course [24]. Similarly, in Australia, microsurfacing can be used where a non-structural wearing course is required and where the increase of the average pavement surface level must be minimised or where a dense graded bituminous surface is desirable at low cost.

\subsection{Application examples}

Because of its vast territories and long hauling distances, Brazil has a strong tradition in the use of BSS and a consistent number of companies own machineries for slurries. The advantages of microsurfacings have made them prevail on slurry seals in most of the country. Nowadays, BSS are normally applied on rural roads, which are controlled by the Government, up to highways and motorways. Microsurfacings are also used on high traffic highways.
In Brazil microsurfacings are used mainly when no major structural damages are visible on the pavement, while minor defects are detected such as ravelling and scuffing. In this case microsurfacings are applied in order to enhance the texture, hence to improve the road safety and correct the surface defects. On major highways, microsurfacings are used on a homogeneous sections basis in order to refurbish the pavement surface and increase the overall road safety. In general, according to the Brazilian experience, microsurfacings are considered cost-effective and to be advantageous in terms of road works duration and traffic disruptions.

Figure 4 and Figure 5 show two examples of microsurfacing application. The first is on a low volume road, the VRS-804, located in the south of Brazil, carrying 975 vehicles per day (12\% of trucks and buses). The second is on a high traffic highway connecting the industrial park to the capital city of Rio Grande do Sul, the BR-290, and carrying 14000 vehicles per day ( $19 \%$ of trucks and buses).

In Italy the use of microsurfacing has gained more and more attention in the recent years, especially due to the lack of funds for traditional road maintenance interventions. These have been traditionally accepted as maintenance interventions to restore the pavements' evenness and skid resistance and, in some cases, as an aesthetic solution. The number of companies that have consolidated experience on this technology is still limited and the predominant use of magmatic rocks, along with the constraints imposed to agencies by the lack of consistent specifications, make it still difficult to be accepted on a regular basis. On the other hand, some attempts have been made to improve the overall conception of microsurfacings and make this technology surge to be used more widely and not only as maintenance solution. Among those attempts, the incorporation of recycled crumb rubber and the use of gap graded curves was proposed by the researchers of the University of Bologna, to provide a pavement with skid resistance and acoustic features (Figure 6). 


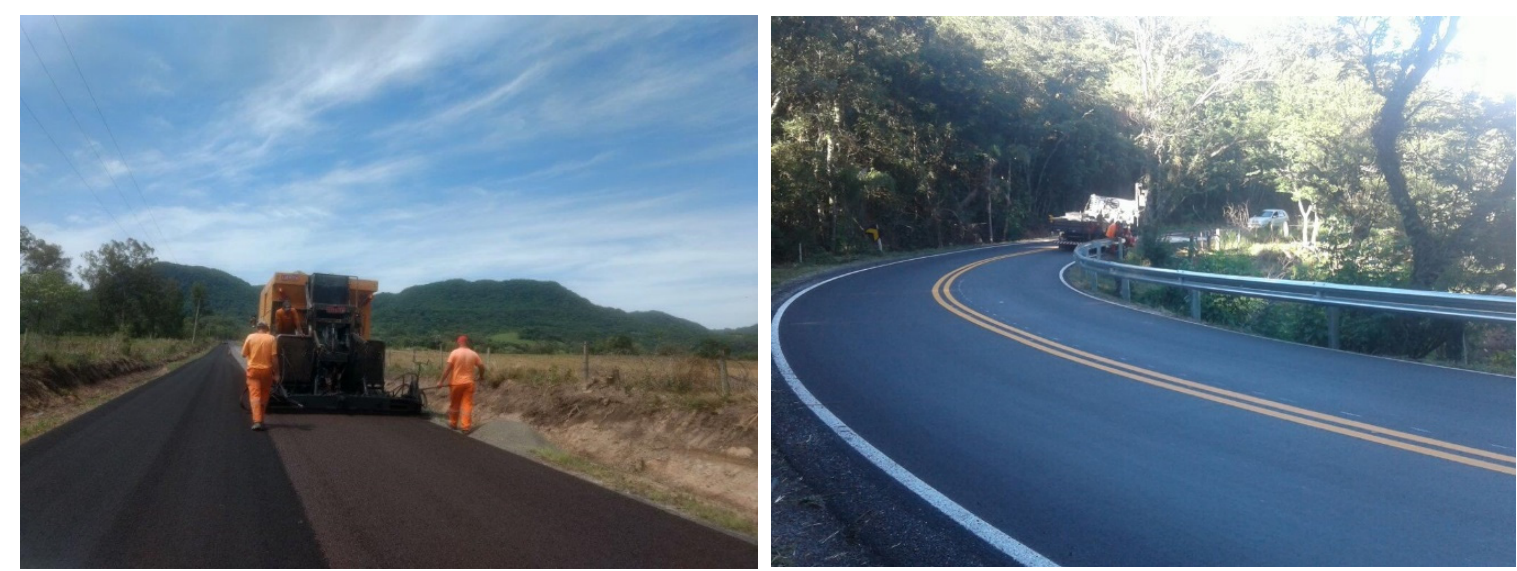

Figure 4. Microsurfacing on VRS-804 road during and after construction.
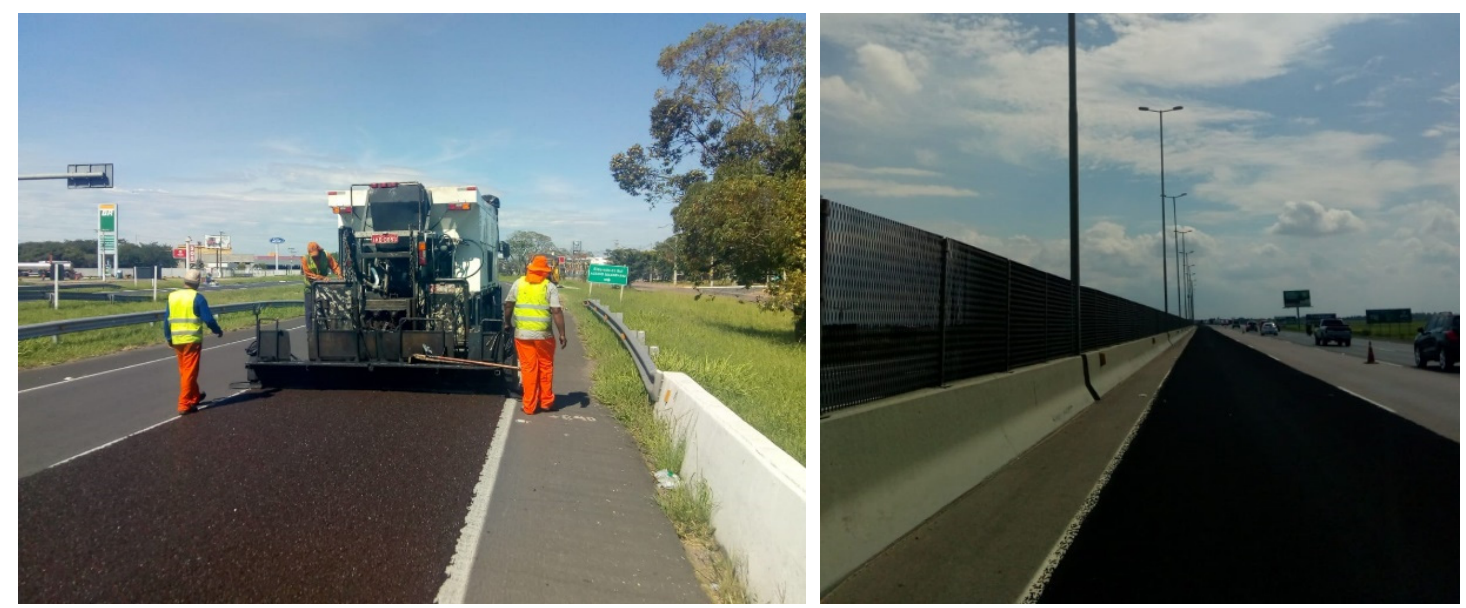

Figure 5. Microsurfacing on high traffic highway, during and after construction.

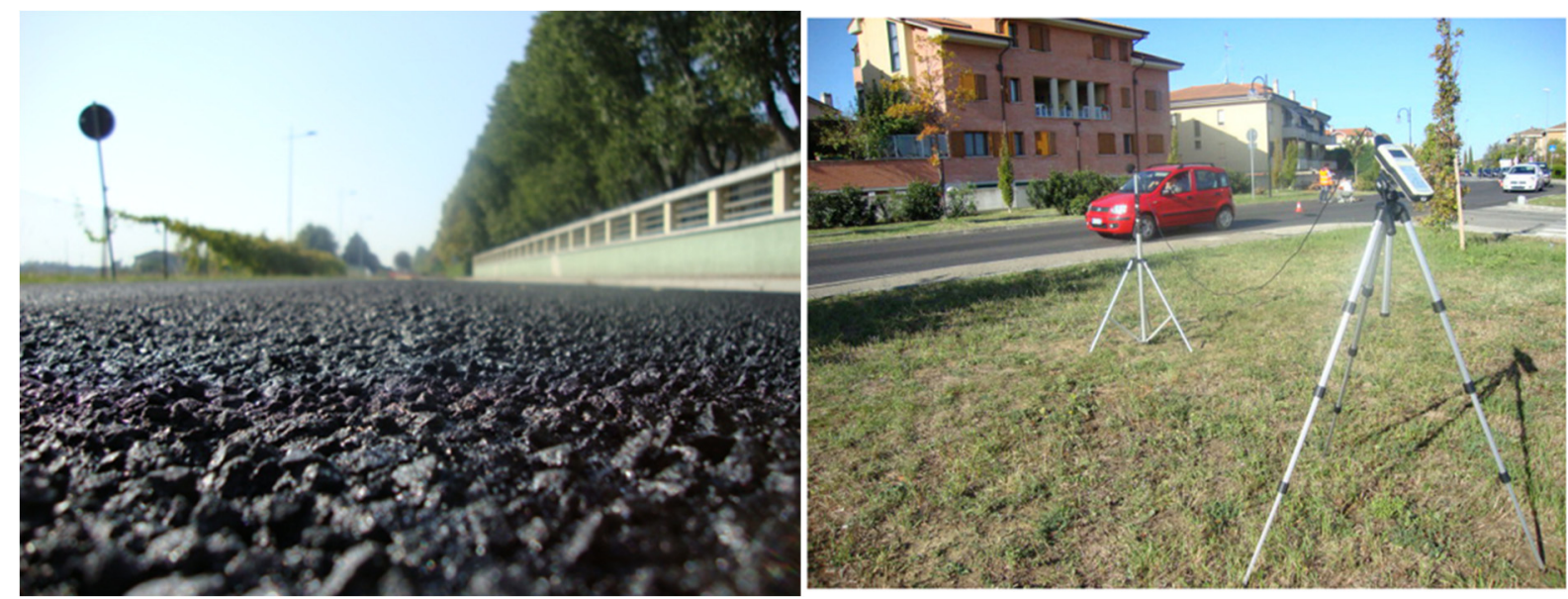

Figure 6. Multifunctional microsurfacings in Ozzano Emilia (Bologna, Italy).

In Canada, microsurfacing is used mostly on low to medium traffic roads, but on some highways with heavy traffic with good results. For example, in Quebec, between 2007 and 2009, several microsurfacing sections on heavy traffic highways, Highway 10, 30 and 70, were constructed with success [27]. The use of BSS is not limited to highways; it has also been used on an airport in Ontario in 2007. In that particular case, it was used on runways and aprons [27]. Microsurfacing have been used since the early 1990s, and they last normally between 4 to 8 years [27]. The use of BBS in Canada is an accepted pavement maintenance technique that extends pavement service life at lower cost than conventional rehabilitation techniques like milling and paving.

\section{Conclusions and further objectives}

After a critical analysis of terminology and use of BSS in ten countries, this paper proposes a more comprehensive and harmonized definition and description of this family of products. 
BSS can be defined as paving mixtures produced using bitumen emulsion and characterized by a "slurry" state. After laying, they evolve into a solid state during a curing process that takes generally from half an hour to twelve hours. Among BSS, microsurfacing and slurry seal can be distinguished. Microsurfacing has higher performance than slurry seal and allows quicker traffic opening, heavier traffic volume and thicker application layers.

BSS are composed of bitumen emulsion, well-graded aggregate blend (including filler), water, and additives (Portland cement, hydrated lime, fly ash or other). Specific additives and fibres may be also be included. Microsurfacing is distinguished by slurry seal for the use of polymer-modified emulsion and higher quality aggregate. Additionally, the nominal maximum size for microsurfacing is often larger than that for slurry seal. BSS are proportioned, mixed and uniformly laid in-place as a homogeneous mat over a properly prepared surface at ambient temperature. They may consist of one or more layers, usually in a thickness of the largest aggregate size in the gradation, that must adhere firmly to the underlying pavement.

BSS are generally used to prevent surface water from penetrating the underlying pavement, to restore or improve skid resistance, to plug superficial voids and microcracking, to provide a distinctive colour to the road surface. Slurry seal is also employed to provide temporary cover at low cost and smooth surfaces for pedestrian areas, parking lots, school yards and bicycle tracks. Microsurfacing is also employed to provide shape correction, to reprofile rutted wheelpaths and to obtain a faster traffic opening.

The RILEM TC 280-CBE will continue the review on BSS including contributions on constituent materials, testing procedures, mix design, equipment, quality control and innovative solutions.

\section{Acknowledgements}

Authors wish to thank James Grenfell (Australia), Paul Marsac (France), Miomir Miljnkovic (Serbia), Fernando Moreno Navarro (Spain), Joel Oliveira (Portugal), Christiane Raab (Switzerland), Shaowen Du (China), Augusto Cannone Falchetto (Germany) and Vaclav Valentin (Czech Republic) to provide the RILEM TC 280-CBE TG2 with extensive technical references.

\section{References}

[1] Syndicat des Fabricants d'Emulsions Routières de Bitume (SFERB), Les Emulsions de Bitume, SFERB, Paris, 1988 (in French).

[2] A. James, Overview of asphalt emulsion. Transportation Research Circular E-C102: Asphalt Emulsion Technology, 1-15, Transportation Research Board, Washington DC, 2006.

[3] Asphalt Institute and Asphalt Emulsion Manufacturers Association, The basic asphalt emulsion manual (MS-19), $4^{\text {th }}$ Ed., Asphalt Institute, 2008.

[4] Multiphase characterisation of cold bitumen emulsion materials Technical Committee 280-CBE (2019, January 25). Retrieved from https://www.rilem.net/groupe/280-cbe-multiphasecharacterisation-of-cold-bitumen-emulsion-materials-371.

[5] Institut des Routes des Rues et des Infrastructures pour la Mobilité (IDRRIM), Guide technique: matériaux bitumineux coulés à froid, CEREMA, Paris, 2017 (in French).

[6] J. Read, D. Whiteoak, The shell bitumen handbook. Thomas Telford, 2003.
[7] CEN European Standard EN 12273, Slurry surfacing - Requirements, European Committee for Standardization, Brussels, 2008.

[8] ASTM Standard D3910, Standard Practices for Design, Testing, and Construction of Slurry Seal, ASTM International, West Conshohocken, PA, 2015.

[9] VSS Norme Suisse SN 640 416-NA, Matériaux bitumineux coulés à froid - spécifications. Annexe nationale EN 12273, Union des Professionnels Suisses de la Route, Zürich, 2011 (in French).

[10] Norma DNIT 035/2005 - ES, Pavimentos flexíveis - Micro revestimento asfáltico a frio com emulsão modificada por polímeroEspecificação de serviço, Departamento Nacional De Infraestrutura De Transportes, Diretoria de Planejamento e Pesquisa / IPR, 2005 (in Portuguese).

[11] UNMZ Česka Technická Norma ČSN 73 6130, Stavba vozovek-Kalové vrstvy. National annex EN 12273, Úřad pro technickou normalizaci, metrologii a státní zkušebnictví, 2016 (in Czech).

[12] Associazione Italiana Bitume Asfalto Strade (SITEB), Emulsioni bituminose: applicazioni, suggerimenti e note tecniche, SITEB, Roma (in Italian), 2004.

[13] International Slurry Surfacing Association (ISSA), Recommended Performance Guideline for Micro Surfacing. Guideline A-143, ISSA, Glen Ellyn, IL, 2010.

[14] International Slurry Surfacing Association (ISSA), Recommended Performance Guidelines for Emulsified Asphalt Slurry Seal Surfaces, Guideline A-105, ISSA, Glen Ellyn, IL, 2010.

[15] Arizona Chapter Associated General Contractors (AZAGC), Micro surfacing and slurry seal guide for application and construction, AZAGC, Phoenix AZ, 2013.

[16] Asociacion Tecnica de Emulsiones Bituminosas (ATEB), Lechadas bituminosas y microaglomerados en frio, 2015 (in Spanish).

[17] F. J. L. Ochoa, M. del Mar Colás Victoria, D. A. García, Microaglomerados en frío y lechadas bituminosas: rehabilitacion superficial de los firmes de carreteras. ATEB comunicacion 22, 2015 (in Spanish).

[18] J. A. Pereira Ceratti, R. M. Martins de Reis, Manual de microrrevestimento asfaltico a frio. Instituto Pavimentar, Rio De Janeiro, 2011 (in Portuguese).

[19] Austroads, Guidelines and specification for bituminous slurry surfacing. Publication AP-T26/03, Austroads Incorporated, Sydney, NSW, 2003.

[20] Centro Sperimentale Interuniversitario di Ricerca Stradale (CIRS). Norme tecniche di tipo prestazionale per capitolati speciali d'appalto, CIRS, Ancona, 2001 (in Italian).

[21] Ente nazionale per le strade (ANAS), Capitolato Speciale d'Appalto Norme Tecniche, ANAS, Roma, 2011 (in Italian).

[22] Autostrade per l'Italia, Capitolato speciale d'appalto, 2008 (in Italian).

[23] Estradas de Portugal, S.A. Pavimentação, Características dos materiais e Métodos construtivos, 2014 (in Portuguese).

[24] Ministerstvo Dopravy, Emulzní kalové vrstvy, Technické Kvalitativní Podmínky Staveb Pozemních Komunikací, Kapitola 27, 2016, Praha (in Czech).

[25] A. Grilli, La manutenzione stradale tramite il microtappeto a freddo, Strade\&Autostrade, n. 121, 2017 (in Italian).

[26] JTG, Technical Specification for Construction of Highway Asphalt Pavements, JTG F40, 2004 (in Chinese).

[27] A. Kucharek, J.K. Davidson, T. Moore, P. Linton, Performance Review of Micro Surfacing and Slurry Seal Applications in Canada, Canadian Technical Asphalt Association, Annual Conference Procceding, 2010, Edmonton, Canada. 